\title{
Al-Asfār al-Arba'at sebagai Basis Metafisika Mullā Shadrā
}

\author{
Rahmat Effendi \\ Universitas Islam Negeri Sunan Kalijaga Yogyakarta, Indonesia \\ rahmateffendiyessa97@gmail.com
}

\begin{abstract}
Shadrā, who is known as the leader of Islamic philosophy, succeeded in synthesizing various views of the previous schools of thought. His philosophy is known as al-Hikmat al-Muta'äliyat which means transcendent wisdom as a transmission of wisdom that is directly present in a person through inner cultivation and spiritual purity. The synthesis is listed in the magnum opus, namely al-Asfär al-Arba'at. What and how Shadrā builds philosophical ideas on top of mystical and rational approaches is a specialty in Shadrā's philosophy. The existence of a relationship between each travel hierarchy and its philosophy is the focus of discussion in this study. This article is a literature study based on descriptive-analytical and holistic methods. The aim is to reveal how the hierarchy of Sadrā's spiritual journey relates to the building of his philosophy. Then look at the concept holistically that there is a connection between mystical experiences that contribute to building a holistic and diverse philosophical system.
\end{abstract}

Keywords: Mullā Shadrā, al-hikmat al-muta 'āliyat, al-asfār al-arba 'at, hierarchy

\begin{abstract}
Abstrak
Shadrā yang dikenal sebagai pemuncak filsafat Islam berhasil menyintesiskan berbagai pandangan aliran pemikiran yang ada sebelumnya. Filsafatnya yang dikenal dengan sebutan al-Hikmat al-Muta'āliyat yang berarti kebijaksanaan transenden sebagai sebuah transmisi hikmah yang langsung hadir dalam diri seseorang melalui olah batin dan kesucian rohani. Sintesisnya tercantum dalam magnum opus yaitu al-Asfär al-Arba'at. Apa dan bagaimana Shadrā membangun gagasan filosofis di atas pendekatan mistik dan rasional menjadi kekhasan dalam filsafat Shadrā. Adanya keterkaitan antara setiap hierarki perjalanan dengan filsafatnya menjadi fokus bahasan dalam penelitian ini. Artikel ini adalah penelitian berbasis studi pustaka dengan metode deskriptis-analitis dan holistika. Tujuannya adalah mengungkapkan bagaimana keterkaitan hierarki perjalanan kerohanian Shadrā dengan bangunan filsafatnya. Kemudian melihat konsep tersebut secara holistik bahwa ada keterkaitan pengalaman mistik yang turut memberikan kontribusi dalam membangun sistem filsafat yang holistik dan beragam.
\end{abstract}

Kata Kunci: Mullā Shadrā, al-hikmat al-muta 'āliyat, al-asfār al-arba 'at, hierarki

\section{Pendahuluan}

Filsafat Islam sebagaimana yang dikenal telah mengalami pasang surut dalam khazanah intelektual Islam. Pasang surut tersebut terjadi karena adanya serangan dari alGhazālī melalui karyanya Tahāfut al-Falāsifah. ${ }^{1}$ Dia mengkritik berbagai pemikiran yang melenceng dari para filosof Islam sebelumnya dan menyalahkan al-Fārābī dan Ibn Sīnā. ${ }^{2}$ Serangan ini dibalas oleh Ibn Rusyd dalam rangka menghidupkan filsafat Islam kembali.

${ }^{1}$ A. Khudori Soleh, "Mencermati Sejarah Perkembangan Filsafat Islam," TSAQAFAH 10, no. 1 (31 Mei 2014): 76-77, https://doi.org/10.21111/tsaqafah.v10i1.64.

${ }^{2}$ Sirajuddin Zar, Filsafat Islam: Filosof dan Filsafatnya (Jakarta: Rajawali Pers, 2014), 163-86.

Tribakti: Jurnal Pemikiran Keislaman

Volume 32, Nomor 2, Juli 2021 
Oleh sebagian ahli, filsafat Islam berhenti seketika peninggal Ibn Rusyd. ${ }^{3}$ Jika dikatakan filsafat Islam mundur di kalangan Islam Sunni, maka itu bisa dibenarkan. Akan tetapi tidak di kalangan Islam Syi'ah. Melalui berbagai transmisi karya filosof awal Islam masuk ke dalam khazanah intelektual mereka. Ditambah dengan pemikiran mistik Ibn 'Arabī dan iluminasi al-Suhraward̄̄ al-Maqtūl, menjadikan dunia Islam Syi'ah sebagai tempat yang subur demi tumbuh kembangnya filsafat. ${ }^{4}$

Berabad kemudian, setelah masuk ke dalam khazanah intelektual Islam Syi’ah, sebagaimana diyakini oleh sarjana Muslim dan Barat, lahirlah pada abad pertengahan aliran baru dalam filsafat Islam. Aliran ini dinisbahkan pada pendirinya yaitu Mullā Shadrā dengan sebutan al-Hikmat al-Muta'āliyat. Di tangannya berhasil menyintesiskan berbagai aliran pemikiran Islam, baik itu peripatetik (masyā'iyat), gnostik ('irfānī), dan iluminasi (isyrāq $\bar{\imath})$. Masa ini sebagai masa puncaknya filsafat Islam, karena berhasil menjawab berbagai permasalahan yang belum terselesaikan oleh pemikir sebelumnya. ${ }^{5}$ Pemikiran Shadrā ini tertuang dalam karyanya al-Asfār al-Arba'at, menjadi sebuah karya agung yang terus dikaji kedalaman maknanya. Dalam karya ini, dijelaskan bagaimana bangunan filsafat Shadrā berdiri di atas hierarki perjalanan kerohanian. Setiap perjalanan memiliki makna dan filsafatnya sendiri sesuai dengan tahapan perjalanan.

Menarik untuk dikaji dalam artikel ini adalah adanya hubungan holistik yang erat antara visi sufistik Shadrā melalui asfār dengan filsafat metafisikanya. Hal demikian tidak dimiliki oleh para filosof Islam sebelumnya. Karena dalam aliran atau paradigma sebelumnya, bangunan filsafat berdiri di atas akal saja, atau intuisi saja. Upaya untuk mengkombinasikan belumlah hadir secara utuh dalam sejarah pemikiran Islam. Bahkan oleh al-Suhrawardi al-Maqtul belum pula memberikan sintesa yang menyeluruh. AlSuhrawardi hanya memberikan antitesa terhadap pemikiran peripatetik yang ada. Dengan begitu belum ada yang membangun pemikiran di atas berbagai aliran. Melalui konsep sintesis inilah Shadrā lahir dan memperkenalkannya. ${ }^{6}$

Wacana Mullā Shadrā mengenai bangunan metafisikanya telah banyak diteliti. Terutama dalam hal epistemologi. Sajjad H. Rizvi meneliti bagaimana pengaruh

\footnotetext{
${ }^{3}$ Henry Corbin, History of Islamic Philosophy (London and New York: Routledge, 2014), 244.

${ }^{4}$ Seyyed Hossein Nasr, Islamic Philosophy From Its Origin To The Present: Philosophy In The Land Of Prophecy (New York: State University of New York Press, 2006), 36.

${ }^{5}$ Murtad $\square$ ha Mut hahharī, Filsafat Hikmah: Pengantar Pemikiran Shadra (Bandung: Mizan, 2002), 73-74.

6 Dudi Badruzaman, "Perkembangan Paradigma Epistemologi Dalam Filsafat Islam," KACA (Karunia Cahaya Allah): Jurnal Dialogis Ilmu Ushuluddin 8, no. 2 (15 Agustus 2018): 159-62, https://doi.org/10.36781/kaca.v8i2.3014.
} 
pemikiran Shadrā yang berasal dari akar sejarah pemikiran yang panjang dan tradisi intelektual yang memengaruhinya. ${ }^{7}$ Happy Saputra menjabarkan bagaimana epistemologi Shadrā dibangun atas berbagai aliran pemikiran yang ada, yaitu peripatetik, intuisi, iluminasi, dan ilmu kalam. ${ }^{8}$ Juwaini menjelaskan bagaimana pemikiran Shadrā tersebut lahir dari akar al-Hikmat al-Muta'āliyat, dengan turut membahas aspek ontologis dan epistemologisnya secara umum. ${ }^{9}$ Faiz menganalisa pemikiran Shadrā yang terdiri atas gagasan-gagasan utamanya dalam bingkai ekstensialisme wujud. ${ }^{10}$ Adapun Fathul Mufid menganalisis bagaimana epistemologi Shadrā terbangun di atas konsep ilmu hudhūrī. ${ }^{11}$ Melihat berbagai penelitian di atas, kebaruan dalam penelitian ini adalah menitikberatkan pada betapa besarnya pengaruh al-asfār al-arba 'at terhadap bangunan metafisika Shadrā.

Sebagai sebuah penelitian baru dan berlanjutan, artikel ini akan mengeksplorasi bagaimana Shadrā membangun argumen fisosofisnya di atas konsep empat perjalanan kerohanian tersebut. Pentingnya fokus kajian ini, karena sejauh ini belum ada penelitian yang mengeksplorasi hal tersebut secara komprehensif. Penelitian-penelitian yang ada berkutat dalam ranah ontologis dan epistemologis filsafat Shadrā tanpa melihat hubungan holistik yang erat antara hierarki perjalanan kerohanian dengan konsep filsafatnya. Tujuannya adalah mengungkapkan bahwa asfār dalam konsep perjalanan kerohanian Shadrā bukan hanya sekedar elaborasi antara konsep epistemologi yang bersifat intuitif dan iluminatif. Melainkan juga mengkombinasikan dengan rasio-religius yang bersifat kebijaksanaan transenden tanpa batas. Setiap pemikiran filsafat Shadrā memiliki nilainilai yang mengkombinasikan berbagai epistemologi dalam filsafat Islam. Sehingga pemikiran rasional Shadrā memiliki dasar yang matang berdasar pada syariat, intuitif, dan iluminatif.

${ }^{7}$ Sajjad H. Rizvi, "Philosophy as a Way of Life in the World of Islam: Applying Hadot to the Study of Mullā Ș adrā Shīrāzī (d. 1635)," Bulletin of the School of Oriental and African Studies, University of London 75, no. 1 (2012): 33-45.

${ }^{8}$ Happy Saputra, "Konsep Epistemologi Mulla Shadra," Substantia: Jurnal Ilmu-Ilmu Ushuluddin 18, no. 2 (1 Oktober 2016): 183-96, https://doi.org/10.22373/substantia.v18i2.3005.

9 Juwaini Juwaini, "Pemikiran Filosofi Mulla Sadra," Substantia: Jurnal Ilmu-Ilmu Ushuluddin 15, no. 1 (15 April 2013): 104-13, https://doi.org/10.22373/substantia.v15i1.4887.

${ }^{10}$ Faiz Faiz, "Eksistensialisme Mulla Sadra," TEOSOFI: Jurnal Tasawuf dan Pemikiran Islam 3, no. 2 (2 Desember 2013): 436-61, https://doi.org/10.15642/teosofi.2013.3.2.436-461.

${ }^{11}$ Fathul Mufid, "Metode Memperoleh Ilmu Huduri Menurut Mulla Sadra," Al-Tahrir: Jurnal Pemikiran Islam 12, no. 2 (26 Oktober 2016): 279-297-297, https://doi.org/10.21154/al-tahrir.v12i2.58.

Tribakti: Jurnal Pemikiran Keislaman

Volume 32, Nomor 1, Juli 2021 


\section{Metode}

Artikel ini adalah penelitian berbasis studi kepustakaan (library research) dengan metode deskriptif-analitis dan holistika. Deskriptif-analitis adalah sebuah metode penelitian dengan memaparkan secara komprehensif atas sebuah objek kajian yang diteliti dengan analitis kritis, sehingga tidak luput suatu apapun dari objek penelitian tersebut. ${ }^{12}$ Adapun pendekatan holistika adalah sebuah paradigma dalam penelitian yang memandang objek penelitian tersebut secara menyeluruh dan integral bukan dalam secara atomistik. ${ }^{13}$ Dalam hal kaitannya dengan penelitian ini adalah mendeskripsikan bagaimana pemikiran Mullā Shadrā tersebut dengan analisis-kritis. Kemudian menggunakan pendekatan holistika guna mengungkapkan bahwa filsafat hikmah Shadrā dibangun di atas al-asfār al-arba'at yang utuh. Bahwa adanya keterkaitan antara perjalanan kerohanian dalam hierarki berpikir filosofis Shadrā akan diungkapkan dalam penelitian ini. Sebagai sumber primer dalam penelitian ini adalah karya Mullā Shadrā sebagai magnum opus yaitu kitab al-Hikmat al-Muta'āliyat fì al-Asfār al-'Aqliyyat alArba'at. Sebagai sumber sekundernya adalah penelitian dalam bentuk buku, artikel, maupun laporan yang ditulis oleh peneliti lain yang berkaitan dengan objek kajian tersebut.

\section{Hasil dan Pembahasan}

\section{Bigrafi Ringkas Mullä Shadrā}

Mullā Shadrā lahir dengan nama Muhammad bin Ibrāhīm bin Yahyā al-Qawāmī al-Syirāzī. Dia bergelar Shadr al-Dīn al-Muta'alihīn ${ }^{14}$ dan lebih populer dengan sebutan Mullā Shadrā. ${ }^{15}$ Di kalangan murid-murid serta pengikutnya dia biasa disebut Akhund. Dia lahir di Syīrāz salah satu kota di Iran sekitar tahun 979-980 H/1571-1572 M dari keluarga yang cukup berpengaruh dan terkenal. ${ }^{16}$ Pada masa hidupnya, Shadrā telah

12 Anton Bakker dan Achmad Charris Zubair, Metodologi Penelitian Filsafat (Yogyakarta: Kanisius, 1992), 54.

${ }^{13}$ Bakker dan Zubair, 46-47.

14 Adapun sebutan Shadr al-Dîn merupakan gelar bagi seorang yang memiliki keilmuan Islam yang mendalam dalam berbagai ilmu keislaman. Jadi, tidak hanya ahli dalam satu ilmu atau beberapa ilmu saja, melainkan segala ilmu terkumpul di dalam dirinya. Adapun tambahan al-Muta'alihîn menunjukkan dia sebagai teladan dalam Filosof-filosof Ilahi. Lihat Hossein Ziai dalam Seyyed Hossein Nasr dan Oliver Leaman, History of Islamic Philosophy, vol. 1 (London and New York: Routledge, 1996), 635.

${ }^{15}$ Sebutan Mullā merupakan sebuah penghormatan tertinggi di daerah Persia. Mullā yang dalam bahasa Arabnya berasal dari kata maula yang berarti orang yang utama dan bisa pula diartikan sebagai pelindung. Lihat Syaifan Nur, Filsafat Wujud Mulla Sadra (Yogyakarta: Pustaka Pelajar, 2002), 42.

${ }_{16}$ Jamilat Muhy al-Dîn al-Basytî, Shadr al-Dîn al-Syirâ zî: wa Mauqifuhu al-Nuqudî min alMadzâ hib al-Kalâ miyat (Beirut: Dâ r al-'Ulûm al-'Arabiyyat, 2008), 17. 
melakukan perjalanan haji sebanyak tujuh kali. Pada saat perjalanan pulang haji yang ketujuh pada tahun 1050 H/1640 M dia menderita sakit di Basrah. Kemudian meninggal dunia dan dimakamkan di sana. ${ }^{17}$

Mullā Shadrā mengawali pendidikan melalui ayahnya. Sejak kecil dia telah hafal al-Qur'ān dan hadīts. Pendidikan formal dia tempuh dengan pergi ke Kota Ishfahan. Ketika di Ishfahan, dia belajar dengan dua guru terkemuka yaitu Syaikh Bahā' al-Dīn al'Āmilî dan Mīr Dāmād. ${ }^{18}$ Dari gurunya yang pertama, Shadrā belajar teologi, tasawuf, fiqh, matematika, filsafat, syair, dan astronomi. Namun, secara khususnya dia lebih banyak belajar ilmu-ilmu keagamaan (al-'ulüm al-naqliyyat). Adapun dari gurunya yang kedua, Shadrā banyak mempelajari ilmu-ilmu intelektual (al'ulūm al-'aqliyyat) yang gurunya itu adalah seorang filosof muslim besar yaitu Sayyid Muhammad Bāqir Astrabadi yang lebih dikenal dengan Mīr Dāmād pendiri aliran Ishfahan. ${ }^{19}$ Disebutkan pula Shadrā juga belajar kepada Muhammad Abu al-Qāsim Findiriski atau Mīr Findiriski. ${ }^{20}$ Dari dia Shadrā mengambil penguasaan filsafat peripatetik.

Setelah menyelesaikan masa belajarnya, Shadrā pun mengajar sebagai seorang guru dalam berbagai kajian keislaman, utamanya filsafat iluminasi. Sekian lama berada dalam dunia kosmopolitan yang hiruk-pikuk, Shadrā mengundurkan diri menuju dunia pengasingan untuk menjalani kehidupan yang asketis ('uzlah). Dia memilih pindah ke Kota Kahak dan menetap selama 15 tahun. Di sini dia memperoleh visi spiritual melalui disiplin spiritual yang berupa $d z i k r$ dan $f i k r .{ }^{21}$ Pada masa ini pula dia berhasil menulis karyanya yang terkenal yaitu al-Hikmat al-Muta'āliyat fì al-Asfār al-'Aqliyyat alArba' $a t .^{22}$ Akhir dari kotemplasi lama ini dia kembali mengajar dan banyak menulis buku yang berkaitan dengan aliran al-Hikmat al-Muta'āliyat.

\section{Filsafat al-Hikmat al-Muta'āliyat}

Mullā Shadrā dalam merumuskan bangunan metafisikanya dipengaruhi oleh berbagai aliran yang ada sebelumnya. Hal ini merupakan suatu yang lumrah dalam dunia pemikiran. Tidak mungkin dapat lahir suatu gagasan tanpa ada pengaruh warisan

${ }^{17}$ Nur, Filsafat Wujud Mulla Sadra, 56.

${ }^{18}$ Nasr dan Leaman, History of Islamic Philosophy, 1:636.

${ }^{19}$ Nasr dan Leaman, 1:636.

${ }^{20}$ Seyyed Hossein Nasr, Intelektual Islam: Teologi, Filsafat dan Gnosis, judul asli Theology, Philosophy and Spirituality, terj. Suharsono dan Djamaluddin MZ (Yogyakarta: Pustaka Pelajar, 1996), 77; Majid Fakhry, Sejarah Filsafat Islam: Sebuah Peta Kronologis, original title; A Short Introduction to Islamic Philosophy, Theology and Mysticism, trans. Zaimul Am (Bandung: Mizan, 2001), 133.

${ }^{21}$ Nur, Filsafat Wujud Mulla Sadra, 52.

${ }^{22}$ Nur, 52.

Tribakti: Jurnal Pemikiran Keislaman

Volume 32, Nomor 1, Juli 2021 
sebelumnya. Meskipun demikian, usaha yang dilakukan oleh Shadrā bukan berarti menafikan berbagai aliran pemikiran sebelumnya, melainkan membuat sintesis besar (grand syntesis) dan menjadi pemikiran orisinal Islam. Shadrā juga mendasarkan epistemologinya pada akal, wahyu, dan gnosis. ${ }^{23}$ Sehingga apa yang dilakukan Shadrā bukan hanya sebatas akal semata, melainkan dengan bimbingan wahyu dan pengalaman batin. Sintesa tersebut didirikan di atas berbagai arus pemikiran yang ada, baik itu peripatetik, gnosis, dan iluminasi. Di lain kesempatan Shadrā berterima kasih kepada berbagai aliran pemikiran yang ada tersebut. ${ }^{24}$ Karena dengan berbagai aliran itulah dia dapat merumuskan pemikirannya.

Dalam magnum opus yaitu al-Hikmat al-Muta'āliyat fì al-Asfār al-'Aqliyyat alArba'at menyebutkan bahwa al-asfār sebagai landasan utama dalam menggapai kebenaran. ${ }^{25}$ Kebenaran dan pengetahuan tersebut disebutkan dengan menggunakan kata hikmat yang berarti kebijaksanaan. Dengan begitu secara tidak langsung, Shadrā mendasarkan berbagai pemikirannya pada konsep al-asfār ini. ${ }^{26}$ Al-Suhrawardī telah merumuskan bahwa seorang yang dapat menyatukan pengalaman mistik dan pengetahuan rasio yang turut serta mendapatkan penyinaran Ilahi, kemudian dapat menjelaskan dengan rasio dan demonstratif, maka dialah seorang yang tertinggi dalam mendapatkan kebijaksanaan. Al-Suhrawardī menyebutkan orang tersebut dengan julukan al-Hākim alMuta'ālih. ${ }^{27}$ Atas dasar visi al-Suhrawardī, Mullā Shadrā berupaya dalam menggapai hal tersebut.

Sebelum lebih jauh membahas mengenai asfār, perlu dijelaskan apa yang dimaksud filsafat al-hikmat al-muta'āliyat. Kebijaksanaan (hikmat) merupakan kebijaksanaan hakiki karena dia berasal dari alam transenden (Tuhan) yang langsung hadir dalam diri manusia. ${ }^{28}$ Inilah yang menjadi dasar bagi al-Ghazālī dengan menyebutnya sebagai ilmu ladunn̄̄ dan bagi al-Suhrawardī disebut dengan ilmu

\footnotetext{
${ }^{23}$ Mullā Ș adrā, Kearifan Puncak, original title; Hikmä̆ al- 'Arsyiyä̆, trans. Dimitri Mahayana and Dedi Djuniardi (Yogyakarta: Pustaka Pelajar, 2004). xv.

${ }^{24}$ Fazlur Rahman, The Philosophy of Mulla Sadra (New York: State University of New York Press, 1975), 9-10.

${ }^{25}$ Mullā Ș adrā, al-Hikmă̈ al-Muta 'āliyä̆ fì al-Asfār al-'Aqliyyä̆ al-Arba'ä̈, vol. 1 (Beirūt: Dār Ihyā' al-Turāts al-‘Arab̄i, 1990), 13-18.

26 Sholihan Sholihan, "Al-Hikmah Al-Muta‘āliyyah Pemikiran Metafisika Eksistensialistik Mulla Shadra," Ulumuna 14, no. 1 (30 Juni 2010): 29, https://doi.org/10.20414/ujis.v14i1.226.

${ }^{27}$ Nasr, Intelektual Islam, 79.

${ }^{28}$ Seyyed Hossein Nasr, Al-Hikmah Al-Muta'aliyah Mulla Sadra: Sebuah Terobosan dalam Filsafat Islam, original title; Sadr al-Dîn Shirâzî and his Transendent Theosophy: Backgroud, Life, and Works, trans. Mustamin al-Mandary (Jakarta: Sadra Press, 2017), 55.
} 
hudhūrī. ${ }^{29}$ Dilihat dari sisi ini jelas bahwa Shadrā dalam mendapatkan pengetahuan cenderung mengikuti dua gurunya ini yaitu al-Ghazālī dalam kitabnya Misykāt al-Anwār dan al-Suhrawardī dalam kitabnya Hikmat al-Isyrāq. Atas dasar pengalaman batin inilah Shadrā dapat merumuskan filsafat metafisikanya.

Penggunaan kata al-hikmat bukanlah hanya sekedar penyebutan atas pengalaman yang dirasakan. Kata al-hikmat telah digunakan oleh para pemikir Islam sebelumnya. Di awal masuknya filsafat ke dalam khazanah intelektual Islam, kata tersebut disandingkan dengan kata filsafat dengan makna yang sama. Karena kata filsafat bukanlah asli dari bahasa Arab. Namun, dengan adanya gerakan islamisasi dalam berbagai bidang, maka kata ini pun diserap ke dalam Islam dengan tetap mempertahankan penyebutan dan makna aslinya. $^{30}$

Para pemikir Islam kala itu telah berusaha dalam menafsirkan filsafat. Di antara jalannya adalah mempertemukan antara filsafat dan agama. Keduanya sama membawa kebenaran. Bedanya jika filsafat membawa kebenaran yang bersifat relatif sebagai hasil usaha manusia, sedangkan agama membawa kebenaran dari Yang Maha Mutlak dan mutlak pula kebenarannya. Meskipun begitu, pada perkembangan selanjutnya, kata filsafat tersebut diupayakan untuk diganti dengan kata lain demi menunjukkan keorisinilan khazanah intelektual Islam. Karena filsafat Islam berada pada jalur agama yang kuat, maka diambillah kata al-hikmat sebagaimana digunakan dalam al-Qur' an. ${ }^{31}$ Dengan menggunakan terminologi baru ini semua sepakat dan menunjukkan arti yang sama.

Di sisi lain, penggunaan kata ini adalah dalam rangka menepis opini Barat, utamanya yang gencar dilakukan oleh orientalisme, bahwa filsafat Islam hanya mengislamkan filsafat yang ada sebelumnya. Bahkan filsafat Islam itu tidak ada dan dilarang dalam Islam. Usaha yang dilakukan oleh para orientalis itu adalah sia-sia. Karena filsafat Islam berhasil menunjukkan jati diri yang berbeda dengan filsafat Yunani dan sebelumnya, baik dari segi metode, cakupan, dan objek bahasan. ${ }^{32}$ Maka penggunaan kata

${ }^{29}$ Mengenai dua istilah ini hanya berupa perbedaan semantik. Namun, yang melatarbelakangi alGhazâlî menyebutnya dengan 'ilm ladunny adalah sebagai hasil daripada pengasingan dia dalam praktek sufistiknya. Lebih-lebih lagi, al-Ghazâlî yang memiliki corak belajar yang literalis-autodidak tersebut menggunakan terminologi yang digunakan dalam al-Qur'an. Lihat Q.S. al-Kahfi [18]: 65. Adapun alSuhrawardî tidak demikian. Walau dia menerima pendapat al-Ghazâlî tersebut, dia memiliki terminologi lain. Jika pengetahuan umum sebagai hasil refleksi manusia disebut dengan 'ilm hushûli, maka pengetahuan dan kebijaksanaan yang langsung melesat ke dalam hati sebagai pancaran dari Tuhan adalah 'ilm hudhûri.

${ }^{30}$ Zar, Filsafat Islam: Filosof dan Filsafatnya, 2-3.

${ }^{31}$ Q.S. al-Baqarah [2]: 269.

${ }^{32}$ Muhammad 'Athif al-'Iraqy, Al-Falsafat al-Islamiyyat (Kairo: Dar al-Ma'arif, 1978), 8-14.

Tribakti: Jurnal Pemikiran Keislaman

Volume 32, Nomor 1, Juli 2021 
al-hikmat ini menunjukkan bagaimana kebijaksanaan dalam Islam itu menjadi sebuah anugerah dan penghargaan tertinggi yang didapatkan oleh manusia. Banyak pemikir Islam sebelum Shadrā menggunakan terminologi ini, seperti al-Kindī, al-Fārāb̄̄, Ibn Sīnā, Ibn 'Arabī, al-Suhrawardī, Nashīr al-Dīn al-Thūsī, dan lainnya. ${ }^{33}$ Mereka menggunakan terminologi ini dalam rangka membuat pemikiran orisinil Islam dengan semangat ajaran Islam, berupa al-Quran dan hadits. Atas dasar semangat itu kemudian filsafat Islam atau al-hikmat juga disebut sebagai filsafat kenabian (prophetic philosophy). ${ }^{34}$

Di tangan Mullā Shadrā yang menjadi pelopor dari filsafat hikmah ini, bahkan oleh para pengikutnya yang menjadi madzhabnya, menggunakan terminologi ini secara lebih komprehensif. Karena berasal dari perjalanan kerohanian atau asfār dan mendapatkan pencerahan tertinggi (theosophy transcendent). Di lain kesempatan, Shadrā turut pula menggunakan terminologi filsafat dalam menjelaskan filsafat hikmahnya tersebut. Dalam asfār dia menyebutkan:

"Sesungguhnya filsafat adalah menyempurnakan diri manusia sejauh posibilitas kemanusiaannya melalui pengetahuan terhadap realitas-realitas esensial segala sesuatu sebagaimana adanya dan melalui pembenaran terhadap wujud segala sesuatu itu yang dicapai dengan pembuktian dan bukan berdasarkan opini atau taqlīd. Atau jika engkau menyukainya, engkau bisa mengatakan bahwa filsafat adalah upaya pemberian tatanan objek akal kepada alam sejauh posibilitas manusia untuk mencapai kemiripan dengan Tuhan."35

Dari pernyataan Shadrā di atas jelas bagaimana dia mengaitkan pengertian filsafat yang ada sebelumnya dengan hikmah. Apabila dilihat lebih jauh lagi, tampak bahwa Shadrā dalam merumuskan definisi tersebut berada dalam bimbingan Ilahi. Tidak ada satu kata pun yang tidak lepas dari bimbingan Ilahi. Itulah yang dimaksudkan oleh Shadrā sebagai al-Hikmat al-Muta'āliyat. Karena setiap orang yang telah mencapai derajat alHākim al-Muta'ālih, dia sedang berada dalam bimbingan Tuhannya. Setiap perilakunya adalah mencerminkan perilaku Tuhan. Setiap katanya mencerminkan perkataan Tuhan. Di sinilah letak kekhasan dari al-Hikmat al-Muta'āliyat yang digagas oleh Shadrā. Sebagai hasil daripada olah diri (riyādhat), penyucian jiwa (tazkiyat al-nufus), melatih pikiran, dan mendapatkan pencerahan Ilahi yang disampaikan melalui argumen yang rasional-demonstratif. ${ }^{36}$ Dengan begitu al-hikmat al-muta' āliyat atau teosofi transenden

${ }^{33}$ Fakhry, Sejarah Filsafat Islam: Sebuah Peta Kronologis, original title; A Short Introduction to Islamic Philosophy, Theology and Mysticism, trans. Zaimul Am. xvi.

${ }^{34}$ Corbin, History of Islamic Philosophy, 125.

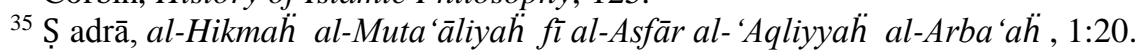

${ }^{36}$ Haidar Bagir, Epistemologi Tasawuf: Sebuah Pengantar (Bandung: Mizan, 2017), 89. 
dapat diartikan sebagai kebijaksanaan tertinggi yang hadir melewati transmisi langsung dari Tuhan ke dalam diri manusia.

\section{Hierarki al-Asfār al-Arba'at dan Bangunan Metafisika}

Mullā Shadrā mendasarkan konsep pemikirannnya dengan konsep empat perjalanan kerohanian atau al-asfār al-'aqliyyat al-arba'at. ${ }^{37}$ Dalam kitab tersebut, Shadrā menggunakan kata 'aql sebagai subjek perjalanan. Namun bukan akal semata yang dimaksud Shadrā. Melainkan adanya perjalanan kerohanian yang menuntun akal diikuti dengan hati yang mendapat pencerahan atau intuisi dari Tuhan. Akal difungsikan sebagai alat abstraksi rasional dan metode dalam menyampaikan argumen yang demonstratif. Adapun hati adalah sebagai alat perasa yang merasakan pengalaman batin sebagai bagian daripada cara mendapatkan pengetahuan presensial. ${ }^{38}$ Itulah sebuah konsep pengetahuan dan kebijaksanaan yang langsung hadir dalam diri manusia.

Al-asfār menjadi dasar dalam berbagai pemikiran Shadrā. Tidak heran bahwa dia meletakkan al-asfār sebagai bagian utama dan pertama dalam karyanya. Karena pada titik inilah yang membedakan dia dengan landasan metafisika filsafat sebelumnya. Jika pada era sebelumnya landasan metafisika bertumpu pada akal semata diwakili oleh kaum paripatetik (masyā'iyat), silogisme diwakili oleh kaum teolog (mutakallimūn), gnosis ('irfān̄i) diwakili oleh tasawuf falsafi Ibn 'Arab̄̄, dan iluminasi (isyrāqū) yang diwakili oleh al-Suhrawardī. Maka bagi Shadrā menyintesiskan berbagai aliran tersebut, sehingga landasan metafisikanya menjadi kokoh dibangun di atas berbagai aliran yang ada. ${ }^{39}$

Sebelum itu, perlu dijelaskan maksud dari padanan kata al-asfār al- 'aqliyyat alarba'at. Hal ini penting, guna menjelaskan lebih lanjut berkenaan dengan konsep metafisikanya. Dalam beberapa literatur yang turut membahas konsep asfār Mullā Shadrā, utamanya kalangan orientalis, mereka mengartikan kata asfār berasal dari kata sifr yang berarti bagian dari buku. Arti ini diambil karena menurut mereka Shadrā ingin menjelaskan bagian-bagian dari bukunya tersebut. Jika dilihat, memang kata safar memiliki akar kata yang sama dengan kata sifr. ${ }^{40}$ Akan tetapi memiliki makna yang berbeda. Maka yang benarnya adalah kata safar yang berarti perjalanan, bukan bagian

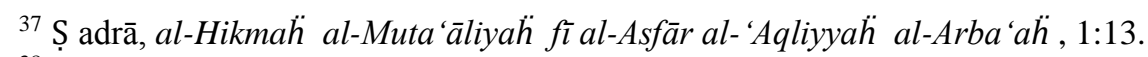

${ }^{38}$ Mehdi Ha'iri Yazdi, Ilmu Hudhuri: Prinsip-Prirnsip Epistemologi Dalam Filsafat Islam, Judul Asli The Principles of Epistemology in Islamic Philosophy, Knowledge by Presence, Terj. Ahsin Mohamad (Bandung: Mizan, 1994), 114.

${ }^{39}$ Nasr, Al-Hikmah Al-Muta'aliyah Mulla Sadra, 54-55.

40 Nasr, 54.

Tribakti: Jurnal Pemikiran Keislaman

Volume 32, Nomor 1, Juli 2021 
buku. Kata asfār adalah bentuk jamak dari kata safar yang berarti perjalanan. Kata safar dalam bahasa Arab menunjukkan pada perjalanan yang jauh ditempuh oleh seseorang. Dengan begitu penggunaan kata jamak asfār menunjukkan banyaknya perjalanan yang harus dilalui oleh seseorang. ${ }^{41}$

Asfār yang dimaksudkan oleh Mullā Shadrā sebagai perjalanan kerohanian melalui empat tahapan. Pada intinya adalah latihan diri (riyādhat al-nafs). Hal ini sama sebagaimana yang dilakukan oleh para sufi klasik seperti, Abū Yazīd al-Busthāmī, Abū Manshūr al-Hallaj, al-Qusyairī, Ibn 'Arabī, dan al-Jillī. Selain daripada melatih mentalspiritual, turut pula melatih akal-intelegensi. ${ }^{42}$ Dalam setiap perjalanan memiliki korespondensi dengan materi filsafatnya. Inilah yang pada akhirnya dalam setiap safar dari asfār memiliki pemikiran filsafat masing-masing. ${ }^{43}$ Korespondesi tersebut berupa hierarki bangunan metafisika yang bermula dari sebuah perjalanan kerohanian (sufistik) dan berakhir dengan makna filosofis.

Ada beberapa terminologi yang digunakan Shadrā dalam menjelaskan safar tersebut. Terminologi ini ditujukan kepada orang yang mendaki perjalanan kerohanian. Terminologi tersebut ada tingkatan, yaitu sālik, 'urafā', dan auliyā'. Kata sālik digunakan untuk menunjukkan keadaan seorang yang akan menempuh perjalanan kerohanian. Kemudian kata 'urafō' jamak dari 'ârif untuk menunjukkan kepada mereka yang ingin mendapatkan pengetahuan dan kebijaksanaan. Terakhir menggunakan kata auliyā' jamak dari wali untuk menunjukkan orang yang telah sampai pada akhir perjalanan. ${ }^{44}$ Adanya beragam penyebutan tersebut bukan berarti Shadrā membuat perbedaan, melainkan menunjukkan tahapan yang dilalui oleh seseorang.

Adapun empat perjalanan kerohanian beserta hierarkinya adalah sebagai berikut.

1. al-Safar min al-khalq ilā al-Haqq bi al-Haqq

Perjalanan pertama adalah perjalanan seorang pemula menjadi seorang yang memiliki visi spiritual. Dimulai sebagaimana perjalanan sufi tingkat awal dengan membersihkan hati melalui berbagai praktek kehidupan yang asketis. Kemudian lanjut

41 Luis Ma'luf, Al-Munjid fi al-Lughat wa al-Adab wa al-'Ulum (Beirut: al-Mathba' at alKatsulikiyyat, t.t.), 337; Muhammad al-Sayyid al-Syarîf al-Jurjânî, Kitâb al-Ta'rifât: Mu'jam Falsafî, Manthiqî, Sufî, Laghwî, Nahwî, tahqîq Abd al-Mun'im al-Hufnî (Kairo: Dâr al-Rasyâd, t.t.), 134-35.

${ }^{42}$ Bachrun Rifa'i dan Hasan Mud'is, Filsafat Tasawuf (Bandung: Pustaka Setia, 2010), 25.

${ }^{43}$ Muhammad Taq̄i Miṣ bāh Yazd̄̄, "Gerakan Substansial dan Prinsipalitas Eksistensi, original title; Two Critical Issues in Sadrian Philosophy: Substantive Motion and Its Relation to the Problem of Time, and the Principality of Existence," dalam Menuju Kesempurnaan: Persepsi Dalam Pemikiran Mulla Sadra (Makassar: Penerbit Safinah, 2003), 177.

${ }^{44}$ al-Jurjânî, Kitâb al-Ta'rifât: Mu'jam Falsafî, Manthiqî, Sufî, Laghwî, Nahwî, tahqîq Abd alMun'im al-Hufnî, 134-35. 
pada tingkatan yang lebih dalam. Shadrā menyebutkan bahwa perjalanan pertama adalah perjalanan dari makhluk menuju Kebenaran bersama Kebenaran melalui penyingkapan hijab-hijab kegelapan dan cahaya yang terbentang antara pesuluk dan realitas spiritualnya, yaitu hijab yang selalu terdapat dalam dirinya. ${ }^{45}$

Perjalanan pertama dimulai dari maqām jasmani (al-nafs) menuju maqām hati (al-qalb), dari maqām al-qalb menuju maqām ruh, dari maqām ruh menuju tujuan tertinggi (al-maqshîd al-aqshâ) seraya menyaksikan keagungan tertinggi (al-bahjat al-kubrā). Pada umumnya sufi hanya sampai pada tiga maqām ini. Akan tetapi, bagi mereka yang telah tersingkap hijabnya, mereka akan melebur bersama-Nya dalam keindahan Ilahi. Hal ini sering disebut dengan lebur di dalam Dzat (al-fanā'fí al-Dzāt). Ketika melebur bersama Tuhannya, dia akan sampai pada maqām rahasia (al-sirr), kemudian tersembunyi (al-khafī), dan yang paling tersembunyi (al-akhfä'). Ketika telah sampai pada tujuan terakhir, sâlik telah sampai pada akhir perjalan pertama. Si sālik telah sampai pada Kebenaran (al-Haqq) dan wujudnya adalah Wujūd al-Haqq. ${ }^{46}$

Dalam perjalanan pertama ini, para filosof dan wali Allah membuktikan keniscayaan Wujūd dan Dzat-Nya melalui kekuasaan-Nya. Mereka melihat kesempurnaan dan tenggelam dalam kesempurnaan itu. Mereka melihat semua wujud kesempurnaan sebagai pancaran cahaya-Nya dan sebagai teofani-Nya. Di sinilah erat kaitannya dengan landasan metafisika Shadrā yaitu ashālat al-wujūd. Ashālat alwujūd Shadrā adalah bahwa tidak ada yang wujud kecuali wujud itu sendiri. Segala entitas mawjūd bergantung pada wujud tersebut. Jadi sebenarnya yang wujud adalah wujud itu sendiri. Dia adalah wujud riil yang berdiri sendiri. ${ }^{47}$

Safar pertama ini Shadrā menjelaskan pandangannya sekitar pengertian filsafat, pembagian, dan kegunaannya. Shadrā menyebutkan bahwa wujūd tersebut adalah Allah SWT yang bersifat swa-wujud dan wujud yang lain bergantung kepada-Nya dalam kesatuan (wahdat al-wujūd). Selanjutnya menjelaskan dalam safar pertama ini bagaimana filsafat wujudnya beserta rangkaian ontologi filsafatnya. ${ }^{48}$ Kemudian masalah wujud dengan mendiskusikan pendapat Ibn Sina atas wujud niscaya (wājib al-wujūd), wujud mungkin (mumkin al-wujūd), dan wujud mustahil (mumtani' alwujūd). Di sinilah Shadrā menjelaskan wujud mental (wujūd al-zhinnī) yang menjadi

\footnotetext{
${ }^{45}$ Ș adrā, al-Hikmä̈ al-Muta 'àliyah̆ fì al-Asfār al-'Aqliyyă̈ al-Arba'ä̈ , 1:13.

46 Ș adrā, $1: 13$.

${ }^{47}$ Ṣ adrā, 1:39.

${ }^{48}$ Nur, Filsafat Wujud Mulla Sadra, 174.
}

Tribakti: Jurnal Pemikiran Keislaman

Volume 32, Nomor 1, Juli 2021 
landasan teosofi transendennya. Selanjutnya secara berurut Shadrā menjelaskan permasalahan gradasi wujud, tingkatan dan kelemahannya atas cahaya wujud. Persoalan kuiditas (māhiyat), relasi bentuk dan materi, serta kausalitas (sebab dan akibat). ${ }^{49}$

2. al-Safar min al-Haqq ilā al-Haqq bi al-Haqq

Perjalanan kedua adalah dari kebenaran menuju kebenaran bersama kebenaran. Perjalanan ini merupakan perjalanan yang dirasakan oleh sālik dalam realitas ketuhanan. Karena dia telah sampai pada wujūd al-Haqq, maka dia mendalami wujūd al-Haqq tersebut hingga mencapai tingkat kewalian. ${ }^{50}$ Pesuluk memulai perjalanan ini dari maqām Dzat menuju maqām kesempurnaan-kesempurnaan (kamāliyyat). Melintasi satu persatu kesempurnaan Tuhan dan mengetahui diri Tuhan kecuali halhal yang tidak dapat diketahui dan dicapai. Kewaliannya menjadi sempurna, karena dia lebur dalam Dzat-Nya. Tindakan dan sifatnya melebur dalam Dzat-Nya itu. Maqām al-sirr sebelumnya adalah keleburan zatnya, al-khafi adalah keleburan tindakan dan sifatnya, dan al-akhfāa' adalah lenyapnya kedua maqām tersebut. Sang sālik telah menjadi wali Tuhan, apa yang ada pada dirinya adalah manifestasi Tuhan. ${ }^{51}$

Hierarki ini merupakan hasil daripada perenungan sālik tentang Wujūd, Pemeliharaan, dan Ketunggalan Tuhan. Mereka juga merenungkan ketunggalan perbuatan-Nya, proses pancaran keragaman yang bersumber dari-Nya dan tingkatantingkatannya hingga rangkaian akal-akal ('uqūl) dan jiwa-jiwa (nufūs) langit, sebagaimana yang diwahyukan, menjadi nyata bagi mereka. Mereka merenungkan alam jabarūt dan malakūt dari tingkatan tertinggi hingga tingkatan terendah yang kemudian berakhir di alam mulk dan nasūt. ${ }^{52}$

Dalam perjalanan kedua ini, Shadrā membahas mengenai filsafat alam. Bagian pertama membahas masalah kuantitas ( $\mathrm{kamm})$. Bagian kedua membahas masalah kualitas (kayf) dan pembagiannya. Kualitas-kualitas ini dalam hal yang terlihat, terdengar, potensial, dan kualitas yang berhubungan dengan jiwa (al-nafs). Turut pula membahas kualitas yang berhubungan dengan kuantitas seperti bentuk lingkaran, geometris, dan lainnya. Bagian ketiga membahas mengenai filsafat alam dengan masalah-masalah yang berada disekitarnya. Bagian keempat membahas masalah fisika

\footnotetext{
${ }^{49}$ Nasr, Al-Hikmah Al-Muta'aliyah Mulla Sadra, 63-64.

${ }^{50}$ S adrā, al-Hikmä̈ al-Muta 'àliyă̈ fì al-Asfār al- 'Aqliyyä̆ al-Arba 'ä̈ , 1:14.

51 Ș adrā, $1: 14$.

${ }^{52}$ Nasr, Al-Hikmah Al-Muta'aliyah Mulla Sadra, 61.
} 
seperti substansi dan pembagiannya, tubuh dan karakteristiknya, bentuk, dan lain-lain. Bagian kelima membahas sifat sementara alam fisik dan pembaruannya secara terusmenerus. $^{53}$

Kemudian masalah penciptaan dari ketiadaan (creatio ex nihilo) dan keabadian alam. Di sini Shadrā mendiskusikannya dengan mencantumkan pandangan-pandangan dari filosof-filosof kuno, seperti Thales, Anaximenes, Empedocles, Phytagoras, Socrates, Plato, dan Aristoteles. Demikian juga mencantumkan pandangan para sufi yang teriluminasi dengan visi gnotis dalam hal kematian wujud material. Bagian terakhir yaitu bagian keenam menjelaskan relasi antara alam dengan prinsip-prinsip metafisikanya, kualitas kepasifan dan reseptifnya di hadapan alam spiritual yang menjadi pengikat antara fenomena-fenomena alam dengan tatanan Ilahi beserta hierarki di alam dunia ini. ${ }^{54}$

3. al-Safar min al-Haqq ilā al-khalq bi al-Haqq

Perjalanan ketiga adalah dari kebenaran menuju makhluk bersama kebenaran. Pesuluk melakukan perjalanan dalam tahap ini melalui tahapan tindakan-tindakan. Meleburannya di sini berakhir dan dia mencapai ketenangan hati yang sempurna. Dia hidup melalui keabadian ( $b a q \bar{a}$ ') Tuhan. Dia melakukan perjalanan melalui alam jabarūt, malakūt, dan nasūt, serta melihat alam-alam tersebut dalam esensi dan keadaannya masing-masing. Dia merasakan kenabian dan mendapatkan pengetahuan ilmu-ilmu Ilahi dari Dzat, sifat-sifat, tindakan-tindakan Tuhan. Akan tetapi, tidak memiliki fungsi kenabian yang membawa hukum-hukum suci. Dia hanya membawa kabar tentang Tuhan, sifat-sifat dan tindakan-tindakan-Nya. Dia tidak menjadi nabi, melainkan mengikuti perintah-perintah dan hukum-hukum dari nabi yang terpilih dan taat kepadanya. ${ }^{55}$

Dalam perjalanan ini jelas bahwa jika pada dua perjalanan sebelumnya, sālik mendaki dari manusia biasa menjadi wujūd al-Haqq kemudian berada dalam wujūd al-Haqq. Maka pada perjalanan ketiga ini sālik turun ke bawah kembali. Karena dia telah menjadi seorang yang tercerahkan sebagai hasil dari perjalanan kedua. Dia menjadi seorang wali Allah (ahl Allah). Menjalankan perintah Allah sebagaimana risalah yang diturunkan kepada Nabi-Nya. Dia tidak memiliki kapasitas sebagai nabi. Karena risalah kenabian telah terhenti. Akan tetapi dia tetap memiliki kewajiban

\footnotetext{
${ }^{53}$ Nasr, 65-66.

${ }^{54}$ Nasr, 66.

${ }^{55}$ Ș adrā,al-Hikmä̈ al-Muta 'āliyä̆ fì al-Asfār al-'Aqliyyä̈ al-Arba 'ä̈, 1:14.
}

Tribakti: Jurnal Pemikiran Keislaman

Volume 32, Nomor 1, Juli 2021 
selayaknya nabi dan wali yaitu mengajak kepada kebaikan dan menjalankan perintah Tuhan.

Dalam safar ketiga, Shadrā menjelaskan ilmu-ilmu tentang Dzat, Nama, dan sifat-sifat-Nya. Ilmu-ilmu ini dalam istilah tradisional disebut metafisika dalam pengertian khusus (al-ilāhiyyat bi ma'na al-akhash) atau teodisi. Menjelaskan tentang Tuhan sebagai wujud niscaya (Wäjib al-Wujūd), berikut bukti-bukti yang berbedabeda dalam menetapkan wujud-Nya, ketunggalan-Nya dan kesederhanaan-Nya. Kemudian membahas sifat-sifat Tuhan, baik afirmatif (tsubūtiyyah) dan negatif (salbiyyah), serta relasi antara sifat-sifat dan Dzat-Nya. Shadrā membahas persoalan pelik tentang pengetahuan Tuhan terhadap alam. Pandangan-pandangan dari hampir semua madzhab filsafat, kalam, dan tasawuf sebelum dirinya didiskusikan pula. Dari sini Shadrā menawarkan teorinya yang terkenal yaitu teosofi transenden (al-hikmat almuta'āliyat) yang didasarkan pada ide bahwa pengetahuan Tuhan tentang sesuatu adalah realitas atau wujud hakiki sesuatu itu sendiri. ${ }^{56}$

Turut pula di sini dibahas kembali mengenai penciptaan alam dan keabadian Tuhan yang berhubungan dengan sumber manifestasi dan penciptaan. Dalam permasalahan hubungan antara temporal dan yang abadi atau antara alam dan Tuhan (hudūts wa qidām), Shadrā menawarkan gagasannya yaitu gerakan transubstansial (alharakat al-jauhariyat) sebagai ciri khas dari teosofi transendennya. ${ }^{57}$

\section{4. al-Safar min al-khalq ilā al-khalq bi al-Haqq}

Perjalanan keempat adalah dari makhluk menuju makhluk bersama kebenaran. Dalam perjalanan terakhir ini, pesuluk menyaksikan semua makhluk beserta efek dan keadaannya masing-masing. Dia mengetahui kebaikan dan keburukan makhlukmakhluk tersebut, baik secara temporal maupun secara spiritual, yaitu di dunia maupun di akhirat. Dia mengetahui kembalinya makhluk kepada Tuhan dan bagaimana cara kembalinya. Dia menjadi seakan nabi yang mengajak dalam mengerjakan hukum Allah. Dia membawa pengetahuan tentang apa yang dibutuhkan oleh makhluk, apa yang mencelakakannya, apa yang membawa kebaikan baginya, apa yang menyebabkan mereka memperoleh kebahagiaan dan apa yang membawa mereka pada kesengsaraan. Dalam semua ini, dia bersama kebenaran, karena wujudnya telah

${ }^{56}$ Nasr, Al-Hikmah Al-Muta'aliyah Mulla Sadra, 68.

${ }^{57}$ Nasr, 68. 
menyatu dengan kebenaran dan perhatiannya kepada makhluk tidak dapat memalingkan perhatiannya kepada Tuhan. ${ }^{58}$

Shadrā dalam safar keempat ini membahas mengenai psikologi tradisional (' $\mathrm{ilm}$ al-nafs) dan permasalahan eskatologi (al-ma'ād). Sebanyak sebelas bab membahas masalah tersebut dan safar terkahir ini adalah penjelasan Shadrā yang panjang dalam pemikiran metafisikanya. Dimulai daripada perkembangan jiwa dalam bentuk janin di rahim ibunya hingga hari kebangkitan dan pertemuan dengan Tuhan. Shadrā memulainya dengan definisi jiwa dan pembuktiannya. Jiwa hewani serta keterikatannnya dengan materi dan kekuatannya. Jiwa nabati dan fakultas-fakultasnya. Masalah indera-indera turut pula dibahasnya di sini. Dalam hal ini Shadrā turut pula memberikan penekanan khusus pada masalah kesatuan jiwa dan fakta bahwa jiwa memiliki semua fakultas di dalam dirinya, sembari mengkritik pemikiran jiwa oleh Ibn Sina. ${ }^{59}$

Terakhir dalam pembahasan yang amat panjang adalah mengenai kesempurnaan tertinggi yang didapat oleh jiwa insani, serta kebangkitan spiritual dan jasmaniah. Dalam bab ini Shadrā memercayai jasad adalah yang turut dibangkitkan ketika hari berbangkit nanti. ${ }^{60}$ Namun yang dimaksud jasad di sini bukanlah jasad sebagaimana jasad di dunia yang rapuh. Melainkan jasad yang berasal daripada perbuatan manusia di kehidupan sebelumnya sebagai manifestasi demi kehidupan hakiki di akhirat. Pada bab ini Shadrā turut pula membahas mengenai nikmat dan siksa kubur, kebangkitan kembali, perhitungan, dan permasalahan eskatologis lainnya yang berlandaskan pada al-Qur'ān dan hadīts.

Demikianlah metafisika filsafat Shadrā yang dibangun di atas empat perjalanan kerohanian. Catatan penting bahwa Shadrā adalah pendukung argumen kemendasaran wujud (ashālat al-wujūd). Hal ini dibuktikan dalam penjelasannya pada safar pertama, bahwa tidak mungkin dapat memahami filsafatnya tanpa memahami dahulu filsafat wujudnya. Bahwa segala sesuatu memiliki wujud riilnya sendiri. ${ }^{61}$ Meskipun begitu, segala yang wujud bergantung pada Wäjib al-Wujūd. Darinyalah eksistensi wujud yang

\footnotetext{
${ }^{58}$ Ș adrā, al-Hikmä̆ al-Muta 'āliyä̆ fì al-Asfār al-'Aqliyyä̆ al-Arba'ä̈ , 1:14-15.

${ }^{59}$ Nasr, Al-Hikmah Al-Muta'aliyah Mulla Sadra, 69.

${ }^{60}$ Nasr, 70.

${ }^{61}$ Rahman, The Philosophy of Mulla Sadra, 28.
}

Tribakti: Jurnal Pemikiran Keislaman

Volume 32, Nomor 1, Juli 2021 
lain menjadi wujud karena pemberian dari-Nya. ${ }^{62}$ Karena Wäjib al-Wujūd adalah wujud yang sempurna, maka wujud turunannya memiliki kekurangan dan ketidaksempurnaan.

Gradasi wujud (tasykīk al-wujūd) merupakan pengenjawantahan atas filsafat wujudnya tersebut. Hal ini erat kaitannya dengan ketunggalan (wahdat) dan pluralitas (katsrah) wujud. ${ }^{63}$ Pada akhirnya akan membawa kepada pemikiran wahdat al-wujūd Shadrā yang intinya segala wujud adalah dalam realitas plural merupakan bagian daripada ketunggalan. Setiap wujud memiliki wujudnya sendiri dengan berbagai batasan dan kekurangan. Gradasi wujud ini dimulai dari realitas wujud tertinggi hingga realitas wujud terendah.

Sementara gerakan substansial (al-harakat al-jauhariyah) merupakan bagian yang erat dengan filsafat jiwa Shadrā. Didasari pada wujud segala sesuatu pasti memiliki gerakan secara substansi, bukan hanya pada aksiden saja yang memengaruhi atas gerak nyata. ${ }^{64}$ Gerak substansi merupakan suatu daya (quwwat) yang menjadi bawaan dari segala wujud dalam rangka mencapai titik kesempurnaan. Gerak substansi ini bermula dari sifat kekurangan menuju kesempurnaan. ${ }^{65}$ Itulah mengapa erat kaitannya dengan filsafat jiwa. Bagi Shadrā manusia sebagai makhluk mawjūd yang memiliki entitas wujud sendiri memiliki daya (quwwat) sebagai potensialitas dalam bergerak menuju kesempurnaan. Jasad yang melekat dan hidup ini juga mengalami hal demikian. Mulai sejak dalam rahim, bayi, anak-anak, dewasa, hingga menua. Jiwa pun turut demikian. Jiwa yang suci harus kembali lagi kepada Yang Maha Suci Pemilik Wujud (Haqiqat alWujūd) dalam keadaan suci. ${ }^{66}$ Jalannya bagi Shadrā adalah menempuh keempat perjalanan kerohanian tersebut.

Dari filsafat jiwa tersebut dilanjutkan oleh Shadrā tentang permasalah teolog dan filosof terdahulu mengenai akhirat dan kebangkitan. Bagi Shadrā kebangkitan di akhirat adalah pasti. Diri manusia yang akan dibangkitkan adalah jasmani dan rohaninya. Itulah mengapa manusia diturunkan ke dunia, dalam rangka menggapai kesempurnaan menuju akhirat. Bentuk rupa manusia bergantung pada kehidupannya di dunia. Manusia yang

${ }^{62}$ Mullā Ș adrā, Teosofi Islam: Manifestasi-manifestasi Ilahi, original title; al-Maz āhir alIlāhiyyă̈ fï Asrār al-'Ulim al-Kamāliyyah̆, trans. Irwan Kurniawan (Bandung: Pustaka Hidayah, 2005), 48-49.

${ }^{63}$ Muhammad Nur, Wahdah al-Wujud Ibn 'Arabi dan Filsafat Wujud Mulla Shadra (Makassar: Chamran Press, 2012), 68.

${ }^{64}$ Yazdī, "Gerakan Substansial dan Prinsipalitas Eksistensi, original title; Two Critical Issues in Sadrian Philosophy: Substantive Motion and Its Relation to the Problem of Time, and the Principality of Existence," 190-91.

${ }^{65}$ Rahman, The Philosophy of Mulla Sadra, 98.

${ }^{66}$ Ghulam Reza Fayyadl, “Sebuah Pengantar Ilmu Jiwa,” RausyanFikr II, no. 5 (2012): 21. 
sempurna hati dan pikirannya akan mendapatkan kesempurnaan dan kemuliaan pula di akhirat. $^{67}$

Terakhir masalah filsafat kenabian (prophetic philosophy). Bagi Shadrā seseorang yang telah melakukan perjalanan kerohanian sebagaimana dia sebutkan akan memiliki potensi sebagai nabi. Nabi di sini bukan sebagai pembawa berita Tuhan dan syariat, melainkan kedudukannya untuk mengajak manusia pada jalan kebenaran. Mengingatkan, memberi kabar gembira dan mengingatkan sesama manusia. Hal ini yang bagi Shadrā belum dijelaskan oleh para filosof dan pemikir sebelumnya. Memang betul apabila sesorang telah sampai pada derajat akal mustafād maka dia akan dapat berkomunikasi langsung dengan akal aktif ( $\left.f a^{\prime} \bar{a} l\right)$ sama hal dengan para nabi dan rasul yang memiliki akal hads. ${ }^{68}$ Bagi Shadrā penekanan tugas kenabian dan kerasulan itu tetap bagi setiap orang dengan kapasitas dan batasannya sebagai manusia biasa.

\section{Kesimpulan}

Sebagaimana pemaparan di atas, jelas bahwa filsafat metafisika al-Hikmat alMuta'āliyat Mullā Shadrā dibangun di atas hierarki empat perjalanan kerohanian (alAsfār al-Arba'at). Setiap tingkatan perjalanan memiliki makna dan filsafatnya sendiri. Pada dasarnya, filsafat hikmah yang disuguhkan oleh Shadrā adalah konsep filsafat dengan riyādhah yang dapat dilakukan oleh setiap orang. Tentu hal ini harus melalui berbagai tingkatan mistik hingga sampai pada maqam yang tertinggi. Hikmah sebagai anugerah dari Tuhan dapat disampaikan kepada siapapun yang mau untuk menerimanya.

Apa yang dipaparkan oleh Shadrā dalam bangunan metafsikanya tidak lepas dari setiap hierarki perjalanan tersebut. Jelas bahwa antara metode irfan yang berbau asketis dapat dipadukan dengan rasionalitas filosofis dalam membangun argumen. Kemendasaran wujud adalah kunci dalam memahami filsafatnya. Wujud merupakan realitas yang riil dan tidak terbantahkan. Bangunan metafisika Shadrā yang terdiri atas ashālat al-wujūd, tasykīk al-wujūd, al-harakat al-jawhariyat, filsafat jiwa, filsafat kenabian, dan sebagainya tidak dapat dipahami tanpa memahami dahulu filsafat wujudnya. Filsafat wujud itu haruslah melewati batas-batas sufistik-rasionalistikfilosofis.

${ }^{67}$ Kholid Al-Walid, Perjalanan Jiwa Menuju Akhirat: Filsafat Eskatologi Mulla Sadra (Jakarta: Sadra Press, 2012), 185-86.

${ }^{68}$ Yazdī, "Gerakan Substansial dan Prinsipalitas Eksistensi, original title; Two Critical Issues in Sadrian Philosophy: Substantive Motion and Its Relation to the Problem of Time, and the Principality of Existence," 138-39.

Tribakti: Jurnal Pemikiran Keislaman

Volume 32, Nomor 1, Juli 2021 


\section{Daftar Pustaka}

Al-Walid, Kholid. Perjalanan Jiwa Menuju Akhirat: Filsafat Eskatologi Mulla Sadra. Jakarta: Sadra Press, 2012.

Badruzaman, Dudi. "Perkembangan Paradigma Epistemologi Dalam Filsafat Islam." KACA (Karunia Cahaya Allah): Jurnal Dialogis Ilmu Ushuluddin 8, no. 2 (15 Agustus 2018): 155-71. https://doi.org/10.36781/kaca.v8i2.3014.

Bagir, Haidar. Epistemologi Tasawuf: Sebuah Pengantar. Bandung: Mizan, 2017.

Bakker, Anton, dan Achmad Charris Zubair. Metodologi Penelitian Filsafat. Yogyakarta: Kanisius, 1992.

Basytî, Jamilat Muhy al-Dîn al-. Shadr al-Dîn al-Syirâ zî̀: wa Mauqifuhu al-Nuqudî min al-Madzâ hib al-Kalâ miyat. Beirut: Dâ r al-'Ulûm al-’Arabiyyat, 2008.

Corbin, Henry. History of Islamic Philosophy. London and New York: Routledge, 2014.

Faiz, Faiz. "Eksistensialisme Mulla Sadra." TEOSOFI: Jurnal Tasawuf dan Pemikiran Islam 3, no. 2 (2 Desember 2013): 436-61. https://doi.org/10.15642/teosofi.2013.3.2.436-461.

Fakhry, Majid. Sejarah Filsafat Islam: Sebuah Peta Kronologis, original title; A Short Introduction to Islamic Philosophy, Theology and Mysticism, trans. Zaimul Am. Bandung: Mizan, 2001.

Fayyadl, Ghulam Reza. “Sebuah Pengantar Ilmu Jiwa.” RausyanFikr II, no. 5 (2012): 2134.

Iraqy, Muhammad 'Athif al-'. Al-Falsafat al-Islamiyyat. Kairo: Dar al-Ma'arif, 1978.

Jurjânî, Muhammad al-Sayyid al-Syarîf al-. Kitâb al-Ta'rifât: Mu'jam Falsafî, Manthiqî, Sufî, Laghwî, Nahwî, tahqî̀ Abd al-Mun'im al-Hufnî. Kairo: Dâr al-Rasyâd, t.t.

Juwaini, Juwaini. "Pemikiran Filosofi Mulla Sadra." Substantia: Jurnal Ilmu-Ilmu Ushuluddin 15, no. 1 (15 April 2013): 104-13. https://doi.org/10.22373/substantia.v15i1.4887.

Ma'luf, Luis. Al-Munjid fi al-Lughat wa al-Adab wa al-'Ulum. Beirut: al-Mathba' at alKatsulikiyyat, t.t.

Mufid, Fathul. "Metode Memperoleh Ilmu Huduri Menurut Mulla Sadra." Al-Tahrir: Jurnal Pemikiran Islam 12, no. 2 (26 Oktober 2016): 279-297-297. https://doi.org/10.21154/al-tahrir.v12i2.58.

Muṭ hahharī, Murtad $\square$ ha. Filsafat Hikmah: Pengantar Pemikiran Shadra. Bandung: Mizan, 2002.

Nasr, Seyyed Hossein. Al-Hikmah Al-Muta'aliyah Mulla Sadra: Sebuah Terobosan dalam Filsafat Islam, original title; Sadr al-Dîn Shirâzî and his Transendent Theosophy: Backgroud, Life, and Works, trans. Mustamin al-Mandary. Jakarta: Sadra Press, 2017. 
- Intelektual Islam: Teologi, Filsafat dan Gnosis, judul asli Theology, Philosophy and Spirituality, terj. Suharsono dan Djamaluddin MZ. Yogyakarta: Pustaka Pelajar, 1996.

- Islamic Philosophy From Its Origin To The Present: Philosophy In The Land Of Prophecy. New York: State University of New York Press, 2006.

Nasr, Seyyed Hossein, dan Oliver Leaman. History of Islamic Philosophy. Vol. 1. London and New York: Routledge, 1996.

Nur, Muhammad. Wahdah al-Wujud Ibn 'Arabi dan Filsafat Wujud Mulla Shadra. Makassar: Chamran Press, 2012.

Nur, Syaifan. Filsafat Wujud Mulla Sadra. Yogyakarta: Pustaka Pelajar, 2002.

Rahman, Fazlur. The Philosophy of Mulla Sadra. New York: State University of New York Press, 1975.

Rifa'i, Bachrun, dan Hasan Mud'is. Filsafat Tasawuf. Bandung: Pustaka Setia, 2010.

Rizvi, Sajjad H. "Philosophy as a Way of Life in the World of Islam: Applying Hadot to the Study of Mullā Ș adrā Shīrāzī (d. 1635)." Bulletin of the School of Oriental and African Studies, University of London 75, no. 1 (2012): 33-45.

Ș adrā, Mullā. al-Hikmä̆ al-Muta'āliyä̆ fì al-Asfār al-'Aqliyyä̆ al-Arba 'ä̆ . Vol. 1. Beirūt: Dār Ihyā' al-Turāts al-'Arabī, 1990.

-. Kearifan Puncak, original title; Hikmah̆ al- 'Arsyiyä̆, trans. Dimitri Mahayana and Dedi Djuniardi. Yogyakarta: Pustaka Pelajar, 2004.

_. Teosofi Islam: Manifestasi-manifestasi Ilahi, original title; al-Maz āhir alIlāhiyyä̆ fì Asrār al-'Ulim al-Kamāliyyä̆, trans. Irwan Kurniawan. Bandung: Pustaka Hidayah, 2005.

Saputra, Happy. "Konsep Epistemologi Mulla Shadra." Substantia: Jurnal Ilmu-Ilmu Ushuluddin 18, no. 2 (1 Oktober 2016): 183-96. https://doi.org/10.22373/substantia.v18i2.3005.

Sholihan, Sholihan. "Al-Hikmah Al-Muta 'āliyyah Pemikiran Metafisika Eksistensialistik Mulla Shadra." Ulumuna 14, no. 1 (30 Juni 2010): 21-38. https://doi.org/10.20414/ujis.v14i1.226.

Soleh, A. Khudori. "Mencermati Sejarah Perkembangan Filsafat Islam.” TSAQAFAH 10, no. 1 (31 Mei 2014): 63-84. https://doi.org/10.21111/tsaqafah.v10i1.64.

Yazdi, Mehdi Ha'iri. Ilmu Hudhuri: Prinsip-Prirnsip Epistemologi Dalam Filsafat Islam, Judul Asli The Principles of Epistemology in Islamic Philosophy, Knowledge by Presence, Terj. Ahsin Mohamad. Bandung: Mizan, 1994.

Yazdī, Muhammad Taqī Miṣ bāh. "Gerakan Substansial dan Prinsipalitas Eksistensi, original title; Two Critical Issues in Sadrian Philosophy: Substantive Motion and Its Relation to the Problem of Time, and the Principality of Existence." Dalam 
Menuju Kesempurnaan: Persepsi Dalam Pemikiran Mulla Sadra. Makassar: Penerbit Safinah, 2003.

Zar, Sirajuddin. Filsafat Islam: Filosof dan Filsafatnya. Jakarta: Rajawali Pers, 2014. 